\title{
perdagangan lada di lampung dalam tiga masa (1653-1930)*
}

\section{PEPPER TRADE IN LAMPUNG IN THREE ERAS (1653-1930)}

\author{
Iim Imadudin \\ Balai Pelestarian Nilai Budaya Jawa Barat \\ Jln. Cinambo No.136 Ujungberung-Bandung 42094 \\ e-mail: iim.imadudin@yahoo.com/imadudin75@gmail.com

\begin{abstract}
Abstrak
Artikel ini bertujuan mengungkap dinamika perdagangan lada di Lampung dalam tiga sistem politik. Penelitian ini mempergunakan metode sejarah yang terdiri atas heuristik, kritik, interpretasi, dan historiografi. Perebutan pengaruh di kawasan tersebut tercipta dalam pola dominasi dan subordinasi. Lampung sebagai penghasil lada berada dalam pengaruh Banten, VOC, dan pemerintah Hindia Belanda. Dengan demikian, tidak terhindarkan berlangsungnya eksploitasi ekonomi di dalam hubungan tersebut. Hasil penelitian memperlihatkan bahwa dinamika perdagangan lada di Lampung tidak terlepas dari berbagai pihak yang bersaing. Para pemainnya adalah Kesultanan Banten, VOC, dan pemerintah Hindia Belanda. Namun, tidak dapat dikesampingkan peranan elit lokal Lampung. Memudarnya perdagangan lada, selain karena faktor internal, seperti tidak optimalnya pemeliharaan kebun lada, juga disebabkan menurunnya permintaan dari pasar internasional. Faktor monopoli perdagangan lada oleh kekuatan asing turut menghancurkan sistem perdagangan lada yang telah berlangsung cukup lama.
\end{abstract}

Kata kunci: perdagangan, lada, sistem politik, Lampung.

\begin{abstract}
This article aims to reveal the dynamics of the pepper trade in Lampung in three political systems. The study uses historical method consists of heuristics, criticism, interpretation, and historiography. The struggle for influence in the region is created in the pattern of domination and subordination. Lampung as the pepper producer is under the influence of Banten, VOC, and the Dutch government. Thus, it is inevitable that there isthe economic exploitation in the relationship. The study shows that the dynamics of the pepper trade in Lampung cannot be separated from the various competing parties. The players are Sultanate of Banten, VOC, and the Dutch government. However, the role of local elites of Lampungis also taken into account. The waning of pepper trade, in addition to internal factors such as not optimal maintenance of pepper garden, also due to lower demand from the international market. The monopoly factor of the pepper trade by foreign powers also crushes the pepper trade system that has lasted long enough.
\end{abstract}

Keywords: trade, pepper, political system, Lampung.

\footnotetext{
* Artikel ini merupakan pengembangan dari makalah yang disampaikan dalam Seminar Hasil Penelitian BPNB se-Indonesia, Makasar, 25 s.d. 28 April 2016. Penambahan dilakukan pada data baru dan pendekatan teori serta konsepnya.
} 


\section{A. PENDAHULUAN}

Beberapa tahun belakangan ini wacana untuk membangkitkan kejayaan lada di Provinsi Lampung mencuat kembali. Dasar dari upaya tersebut adalah pengalaman historis bahwa bumi Lampung pernah menjadi salah satu penghasil lada terbesar di Nusantara. Julukan Lampung tanoh lado melekat lebih dari setengah abad lampau.

Memori tersebut samar-samar masih terkenang pada generasi yang lebih tua. Sebuah lagu yang berjudul "Tanoh Lado" merekam ingatan kolektif tentang kejayaan Lampung sebagai penghasil lada hitam di masa lalu. Kenangan itu pula yang menginspirasi pemerintah daerah dan masyarakat Lampung menjadikan lada hitam sebagai salah satu bagian lambang daerah ketika Provinsi Lampung diresmikan pada tanggal 18 Maret 1964.

Harapan tersebut memang berbanding terbalik dengan realitas kekinian. Jejaknya belum terlalu jauh. Sekurangkurangnya dua puluh tahun terakhir, perkebunan lada hitam di sana tak terurus. Pemerintah Daerah setempat hanya meraup sedikit sumber devisa dari sektor tersebut.

Pada tahun 2000 komoditas ekspor lada hanya menyumbang 15,18 persen dari total ekspor. Ribuan hektar kebun lada banyak ditinggalkan sebab jenis rempah itu diserang penyakit busuk pangkal batang. Selain itu, produktivitasnya minim yakni berkisar antara 300 sampai 500 kilogram per hektar. ${ }^{1}$

Lada dalam sejarah Lampung telah melalui perjalanan panjang. Pada masa kekuasaan Banten, kesultanan melakukan kontrol yang kuat atas daerah-daerah penghasil lada, seperti Lampung, Palembang, Bengkulu, dan Jambi. Ketiga nama terakhir akhirnya melepaskan diri dari pengaruh Banten. Sementara, Lampung dalam jangka waktu yang cukup lama dipengaruhi, dan memberi surplus pada Kesultanan Banten.

\footnotetext{
${ }^{1}$ http://news.liputan6.com/read/5296/pemdalampung-membangkitkan-bisnis-lada-hitam, diakses 28 Juni 2016 pukul 8.56 WIB.
}

Bumi ruwa jurai menjadi wilayah perebutan pengaruh Palembang dan Banten sebelum masuknya kolonialisme. Persaingan itu yang mendorong Kesultanan Banten mengirimkan ekspedisi militer yang dipimpin Maulana Muhammad (1580-1596) untuk menak-lukkan Palembang. Namun, serangan tersebut mengalami kegagalan. (Ekadjati, 1997: 21).

Pada masa VOC, perdagangan lada dimonopoli. Setelah VOC mengalami kebangkrutan, pemerintah Hindia Belanda mengambil alih penguasaan lada di Lampung. Kekuasaan Belanda di Lampung berpusat di Tulang Bawang. Pada masa tanam paksa (1830-1870), pemerintah memaksa petani lada menjual lada kepada pemerintah melalui tangan kepala-kepala marga.

Kajian mengenai perdagangan lada di Lampung telah ditulis beberapa penulis sebelumnya. Edi S. Ekadjati (1995) mengungkap peranan Kesultanan Banten dalam hubungannya dengan wilayah luar. Atsushi Ota menulis pembajakan yang terjadi di Selat Sunda pada abad ke-19. Iim Imadudin (2008) mendeskripsikan hubungan Lampung-Banten dalam perspektif sejarah. Laelatul Masroh (2015) mendeskripsikan perkembangan perke-bunan dan perdagangan lada di Lampung 1816-1942. Artikel ini memiliki perbedaan dengan artikel dengan tema yang ditulis sebelumnya. Pertama, artikel ini mencoba melihat dalam perspektif yang lebih luas, tidak hanya soal perdagangan, tetapi juga adanya dominasi politik dan ekonomi. Kedua, dilihat dari rentang waktunya yang panjang, artikel ini membandingkan perdagangan lada dalam penguasaan politik yang berbeda-beda.

Kajian tentang perniagaan lada di Lampung menarik untuk dilakukan. Secara metodologis, Ilmu Sejarah dalam menghubungkan dirinya dengan masa kini menggunakan tiga pendekatan (Kuntowijoyo, 2003: xviii). Pertama, pendekatan genetis. Melalui pendekatan ini dapat diketahui bagaimana dinamika penanaman dan perdagangan lada 
Lampung. Ada kontinuitas dan diskontinuitas, serta fase pasang-surut. Kedua, pendekatan komparasi, melalui pendekatan ini dapat diketahui perkembangan ekonomi dalam sistem politik yang berbeda-beda, yakni masa Kesultanan Banten, VOC, dan pemerintah Hindia Belanda. Ketiga, paralelisme historis, melalui pendekatan ini dapat dimengerti adanya pola-pola penguasaan dalam distribusi perdagangan lada. Secara umum, lada Lampung sebagai topik kajian yang menarik (interesting topic) ditentukan bukan hanya karena faktor lada, tetapi mengingat peristiwa kelampauan yang mewarnai dinamika sosial, ekonomi, dan budaya di wilayah tersebut. Selain topiknya menarik, kajian ini juga memiliki arti penting bagi upaya membangkitkan kembali ekonomi lada yang mulai berkembang sekarang ini. ${ }^{2}$

\section{B. METODE PENELITIAN}

Penulisan artikel ini menggunakan metode sejarah. Metode sejarah adalah proses menguji dan menganalisis secara kritis rekaman dan peninggalan masa lampau berdasarkan data yang diperoleh (Gottschalk, 1985: 39). Gilbert J. Garraghan (1957: 33) mendefinisikan metode sejarah sebagai seperangkat aturan dan prinsip-prinsip yang sistematis untuk mengumpulkan sumber-sumber sejarah secara efektif, menilainya secara kritis, dan menyajikan sintesis dari hasil-hasil yang dipakai dalam bentuk tertulis.

Metode sejarah terdiri atas empat tahapan. Tahap pertama, heuristik, yaitu melakukan pencarian sumber yang berkaitan dengan objek yang diteliti melalui penelitian di perpustakaan (library research). Literatur diperoleh melalui studi pustaka di Perpustakaan Wilayah Jawa

2 Penulisan sejarah memiliki persyaratan menyangkut topik yang akan ditulis. Topik yang ditulis harus memenuhi syarat, antara lain menarik (interesting topic), memiliki arti penting (significant), dan dapat dikerjakan karena sumber-sumbernya tersedia dan dapat diperoleh (manageable topic) (Hardjasaputra, 2013).
Barat, Perpustakaan Balar Arkeologi Bandung, PDII LIPI, dan Perpustakaan Universitas Indonesia.

Tahap selanjutnya adalah tahap kritik, dengan membuat perbandingan dari beberapa sumber atau membandingkannya dengan fakta-fakta yang ada sebelumnya. Tahap ketiga adalah interpretasi, yaitu proses menafsirkan berbagai fakta menjadi sebuah rangkaian yang logis. Secara praksis, interpretasi dilakukan secara analitis (menguraikan fakta) dan sintesis (menghimpun fakta). Pemahaman verbal saja tidak memadai untuk menginterpretasikan informasi yang terkandung dalam sumber sejarah. Oleh karena itu, diperlukan pula interpretasi teknis, faktual, logis, dan psikologis. Penggunaan berbagai model interpretasi akan menghasilkan pemahaman yang bersifat menyeluruh dan mendalam. Tahap terakhir adalah penulisan sejarah, fakta-fakta yang telah diinterpretasikan dituliskan dalam suatu penulisan yang sistematis dan kronologis.

Dengan menggunakan metode sejarah, penulis mendapatkan panduan bagaimana secara teknis artikel ini dapat dikerjakan secara efektif dan akurat. Efektif dalam pengertian tahap demi tahap dikerjakan secara tertib. Akurat dalam pengertian hanya sumber yang telah menjadi fakta yang sejarah yang dapat dijadikan bahan penulisan. Selain itu, unsur diakronis yang menunjukkan sejarah sebagai ilmu tentang thinking in time (berpikir dalam waktu) sangat diperhatikan.

Penulis mempergunakan konsep dominasi dan subordinasi untuk menjelaskan pengaruh tiga sistem politik terhadap perniagaan lada di Lampung. Interaksi selalu melahirkan adanya kelompok yang mendominasi dengan kelompok lainnya yang menjadi subordinat. Di antara keduanya berlangsung hubungan timbal balik (Johnson, 1986: 262).

Weber melihat dominasi kekuasaan selalu ada dalam setiap sistem masyarakat. Kekuasaan didefinisikan sebagai sebuah sistem yang memiliki kekuatan untuk 
membuat setiap perintahnya dipatuhi oleh sekelompok orang ( 1978: 212).

Terdapat tiga bentuk dominasi kekuasaan, yaitu dominasi kekuasaan legal rasional, tradisional, dan karismatik (1987: 215). Masing-masing bentuk kekuasaan, menurut Weber, akan menghasilkan sistem ekonomi yang berbeda.

Pihak yang menjadi superordinasi cenderung untuk menghapuskan independensi kelompok yang menjadi subordinat. Dalam hal ini, Kesultanan Banten, VOC, dan Pemerintah Hindia Belanda menjadi superordinasi dengan elit lokal Lampung sebagai subordinatnya

\section{HASIL DAN BAHASAN \\ 1. Masa Kesultanan Banten}

Penguasaan Kesultanan Banten atas Lampung dapat dilacak dari situasi internal masyarakat Lampung. Setelah keruntuhan Kerajaan Tulang Bawang, tidak ada lagi otoritas politik yang berkuasa. Pemerintahan telah berganti dalam bentuk keratuan. Pada tahun 1530, Lampung terbagi atas wilayah keratuan (persekutuan hukum adat) yang terdiri atas Keratuan di Puncak menguasai wilayah Abung dan Tulang Bawang; Keratuan Pemanggilan berkuasa di Krui, Ranau, dan Komering; Keratuan di Pugung menguasai wilayah Pugung dan Pubian; serta Keratuan di Balaw berkuasa di Teluk Betung. Ketika Banten menguasai Lampung, Keratuan di Pugung dibagi menjadi Keratuan Maringgai (Melinting) dan Keratuan Darah Putih (Kalianda) (Saptono, 2010: 85-86).

Pada abad ke-17-18 penguasa keratuan membentuk pemerintahan persekutuan adat berdasarkan buay (keturunan) dikenal dengan paksi (kesatuan buay inti atau klan) dan marga yang merupakan kesatuan bagian dari buay atau jurai dalam bentuk kesatuan kampung atau suku (Hadikusuma, 1989: 157).

Marga atau mego dalam perkembangannya menjadi republikrepublik mini yang bersaing satu sama lain. Akibatnya, tidak ada satu kepemim- pinan yang kuat yang menyatukan margamarga. Kondisi ini membuat pihak luar dapat dengan leluasa menaklukkan tanah Lampung. Daerah sepanjang Sungai Komering dikuasai Palembang, sedangkan Banten berkuasa di Silebar dan Semangka (ANRI, 1973: lxxxv-lxxxvi).

Oleh karena persaingan yang keras di antara sesama marga, para pemuka marga mencari dukungan kepada penguasa yang lebih kuat, yang dalam hal ini Kesultanan Banten. Mereka melakukan seba ke Banten sebagai tanda pengakuan terhadap kekuasaan Banten. Sultan Banten memberikan berbagai gelar, antara lain punggawa, pangeran, ngabehi, jenang, dan radin. Selain itu, sultan memberikan benda-benda, seperti lawang kuri, payung, keris, siger, pepadon, dan lain-lain (Bukry et al., 1997/1998: 57).

Sebagai wilayah yang dikuasai, Sultan Banten melakukan eksploitasi ekonomi, khususnya dalam tata niaga lada. Penarikan lada dari Lampung terus diintensifkan. Kebijakan ini dilakukan sultan setelah produksi lada di Banten mengalami penurunan pada abad ke-17, sementara kebun lada di Lampung terus bertambah (Ota, 2015: 171).

Sultan mengeluarkan berbagai piagam (pijagem) yang berisi sejumlah peraturan yang mengikat. Pada tahun 1653 Sultan Ageng mengeluarkan peraturan yang mewajibkan penduduk Lampung menanam lada 500 pohon per orang, dan menjualnya pada pembeli tanpa memandang kebangsaannya. Orang Jawa, Cina, Inggris, atau Belanda dapat membeli lada secara bebas (Untoro, 1998: 155).

Sultan mengeluarkan Piagam Sukau yang berhurup Lampung dan berbahasa Jawa Banten bertahun $1104 \mathrm{H}$ (1684 M). Piagam tersebut berisi kewenangan Sultan Banten mengangkat dan memecat kepala-kepala daerah. Orang Lampung diwajibkan mengumpulkan lada, khususnya orang cilik serta segenap punggawa diharuskan menanam merica sebanyak 500 pohon setiap orang, terma- 
suk seluruh penduduk yang telah berusia 16 tahun.

Prasasti yang berasal dari Bojong berhurup Arab tertanggal 30 Jumadil Akhir $1102 \mathrm{H}(1691 \mathrm{M})$ berisi aturan perdagangan lada di Lampung. Penjualan lada harus di bawah kontrol Sultan Banten. Penjualan lada bukan hanya diawasi, bahkan sultan pula yang memutuskan kepada siapa lada dijual. Pelanggaran terhadap kebijakan tersebut dikenakan sanksi berupa penahanan dan pengusiran. Cukup banyak piagam atau prasasti yang mengatur tata niaga lada, di antaranya prasasti berangka tahun 1746, 1761, dan 1777 (Imadudin, 2008: 1476).

Sebagai bentuk pengendalian terhadap tata niaga lada, penguasa Banten menempatkan jenjen (jinjam atau jenang) di Semangka (Kota Agung). Karena hanya berurusan dengan soal lada, jenjen tidak mencampuri urusan pemerintahan. Dengan posisi demikian, elit lokal Lampung yang terpencar-pencar yang disebut "adipati" secara hirarkis tidak berada di bawah perintah jinjam (Rijal, 2011: 40). Tugas utama jenjen adalah mengelola penerimaan lada dari Lampung dan mendistribusikannya ke Bandar Banten (Gonggong, 1993: 20). Selanjutnya, Sultan Banten menugaskan para punggawa sebagai wakilnya di Tulang Bawang, Sekampung, dan Semangka (Gonggong, 1993: 28).

Daerah penghasil lada yang utama di Lampung adalah Tulang Bawang, Sekampung, Semangka, dan Seputeh (Gonggong, 1993: 28; Sayuti, 1993: 3). Tome Pires yang berlayar dari Laut Merah ke Cina pada 1512 hingga 1515 menceritakan ihwal produksi lada di Tulang Bawang dan Sekampung. Tulang Bawang dan Sekampung merupakan daerah penghasil lada. Transportasi dilakukan melalui sungai. Kedua daerah itu sudah melakukan kontak perdagangan dengan Sunda dan Jawa dengan lama perjalanan satu hingga dua hari (Cortesão, 2015: 222; Juliadi, 2014: 48; Saptono, 2010: 83).
Setelah Malaka jatuh ke tangan Portugis pada tahun 1511, jalur perdagangan melalui Aceh dan Selat Sunda semakin ramai. Para pedagang muslim yang memusuhi Portugis memindahkan transaksi komoditasnya ke jalur utara (Aceh) dan ke selatan (pelabuhan Banten). Dalam posisi demikian, Bandar Banten bertambah strategis. Kafilah dagang tidak lagi memiliki persinggahan di pantai utara Jawa, setelah memudarnya kota-kota pelabuhan di pesisir Jawa Tengah dan Jawa Timur. Selain itu, posisi Banten cenderung aman dari kemungkinan serangan Mataram (Kartodirdjo, 1987: 68).

Perniagaan lada yang semakin meningkat pada gilirannya menumbuhkan kota-kota dagang di pesisir Lampung. Di Kota Teluk Betung, para pedagang berkumpul membawa barang-barang, setelah melalui aliran sungai dan pantai antara lain, Pelabuhan Sukamenanti, Bandar Balak, Bandar Lunik, dan Bandar Teba. Tumenggung Nata Negara yang ditunjuk Banten bertindak sebagai adipati di Teluk Betung, yang memerintah 3000 penduduk (Yusuf, 1984: 23).

Bandar-bandar di pesisir Lampung ramai didatangi para pedagang membentuk jaringan perdagangan Nusantara. Kisah Nahkoda Mangkuto dan Nahkoda Muda menggambarkan kejayaan perdagangan lada di Lampung. Nakhoda Mangkuto adalah saudagar Minangkabau yang menjadi pedagang lintas pulau yang bergerak di antara Pulau Sumatera, Jawa, Kalimantan, dan Karimata. Setelah berdagang ke banyak pulau, ia bermukim di Piabung Lampung dan melakukan perdagangan lada dengan wilayah Banten. Nakhoda Mangkuto meninggal dunia tahun 1740. Perdagangan lada dilanjutkan anaknya yang bernama Tayan, lebih dikenal dengan nama Nakhoda Muda. Keberhasilan Nakhoda Muda dalam perniagaan membuat dirinya menjadi orang kaya dan berpengaruh (Drewes, 1961).

Koopman de Jager dalam dagregister pejabat VOC Agustus 1682 
mencatat bahwa Desa Kuripan Pesisir, Perwata dan Suti Karang (Teluk Betung) yang terletak di Teluk Lampung merupakan "pabean" dan tempat penimbunan lada dari seluruh daerah Lampung (Yusuf, 1984/1985: 24).

Dari penjabaran di atas dapat digambarkan bahwa bandar-bandar di Lampung memainkan peran sebagai feeder $^{3}$ yang menyuplai lada ke bandar Banten yang menjadi entrepot. Namun, dalam skala yang lebih kecil, bandarbandar kecil menjadi Collecting Centres dalam lokalitas perdagangan di wilayah Lampung. Lada Lampung telah memberi kontribusi besar bagi kemakmuran Kesultanan Banten. Sultan, para bangsawan, dan saudagar hidup dalam kemewahan. Beberapa dari bangsawan memiliki rumah mewah, kapal, dan budak (Untoro, 2006: 168; Guillot, 1990: 32).

\section{Masa VOC}

Sebelum kedatangan VOC, Kesultanan Banten mengalami masa kejayaan. Aktivitas pertanian komersial berkembang dengan pesat. Kontrol terhadap daerah yang dikuasai semakin mantap.

Kondisi tersebut berubah ketika VOC turut campur dalam internal politik Kesultanan Banten. Penobatan Sultan Haji dan konflik dengan Sultan Ageng Tirtayasa adalah strategi VOC untuk

${ }^{3}$ Bandar yang termasuk pada tipe "feeder points" adalah bandar yang letaknya strategis di rute jaringan perdagangan untuk membantu melayani bandar Entrepot dalam transaksi dagang. Bandar ini berhubungan langsung dengan daerah penghasil barang komoditi. Bandar yang bertipe collecting centres adalah bandar tempat menumpuknya berbagai barang komoditi yang datang dari bandar lain untuk dikonsumsi sendiri dan didistribusikan ke daerah pedalaman. Bandar ini didukung oleh hasil bumi di sekitarnya dan terletak di pepesir, atau di hulu sungai yang dekat dengan daerah penghasil barang komoditi. Tipe entrepots adalah bandar yang berfungsi untuk pengumpulan barang yang dibawa oleh kapal dagang dari berbagai negeri, seperti dari Timur Tengah, India, dan Eropa (Nur, 2014: 30). menguasai Banten. VOC menaruh perhatian yang besar terhadap surplus perdagangan lada Lampung. Para pembesar VOC menyaksikan bahwa para bangsawan mampu hidup dengan makmur berkat lada Lampung.

Sebagai upaya menakar potensi sebenarnya dari lada Lampung, VOC mengirim ekspedisi perintis yang dipimpin Willem Caaff. Namun ekspedisi itu tidak mencapai sasaran yang diharapkan (Imadudin, 2008: 1483).

Ekspedisi berikutnya segera dipersiapkan lebih baik. Pada sidang tanggal 22 Juli 1682, ditetapkan ekspedisi ke Lampung dipimpin Koopman dan Everhard van der Schuur. Koopman berangkat lebih dahulu. Selanjutnya, Van der Schuur berangkat dari Batavia, dan tiba di Banten 18 Agustus 1682 (Gonggong, 1993: 22)

Pada tanggal 24 Agustus 1682 van der Schuur berlayar ke Lampung dengan kapal De Smit (kapal pemburu), Den Alexander dan Odick (kapal pengangkut). Dua kompi serdadu Belanda tergabung di dalamnya. Ekspedisi ini mencoba membuka jalan ke arah penguasaan Lampung dan Selebar, yang terletak antara Kesultanan Palembang dan kota Mayuta di daerah Indrapura. Utusan Sultan Haji, Pangeran Nata Negara, dan Aris Wangsa Yuda memimpin empat kapal Kesultanan Banten mengiringi armada VOC (Gonggong, 1993: 22).

Van der Schuur membawa 23 lembar surat untuk melegitimasi ekspedisinya. Ia menyadari ekspedisinya akan menemui rintangan yang tidak mudah dilewati. Pada intinya, surat-surat berisi pesan penting bahwa sudah terjadi peralihan kekuasaan di Banten dari Sultan Ageng Tirtayasa beralih pada Sultan Haji sejak tanggal 22 Agustus 1682. Dalam surat-surat tersebut dinyatakan bahwa Sultan Haji merestui ekspedisi VOC ke Lampung (Imadudin, 2008: 1484).

Tantangan pertama dihadapi ekspedisi saat tiba di Tanjung Tiram tanggal 29 Agustus 1682. Para penduduk 
yang melihat kedatangan armada VOC ramai-ramai lari ke pedalaman. Pangeran Nata Negara segera turun dari kapal. Ia meletakkan surat pada bendera putih yang terpancang di pinggir pantai seraya menjelaskan bahwa kedatangan rombongan untuk berdagang. Mengetahui hal demikian, penduduk kembali ke kampungnya. Van der Schuur tidak mendapatkan komoditas lada yang dicarinya (Gonggong, 1993: 23; Rijal, 2011: 40).

Pada tanggal 30 Agustus 1682 ekspedisi bergerak menuju Karang Kandang (Teluk Semangka), pabean (bea cukai) di daerah Majapahit. Di sini terlihat kegamangan penduduk loyalis Sultan Ageng Tirtayasa. Mereka bingung menerima rombongan VOC yang menjadi sekutu Sultan Haji. Mereka memilih menyingkir ke pedalaman. Namun, para pembesar Banten berhasil membujuk mereka kembali ke rumah. Mulanya VOC merasa heran dengan sikap penduduk. Setelah memperoleh informasi bahwa kebanyakan penduduk menjadi pendukung Sultan Ageng, barulah mereka mengerti. Ketika Banten berhasil dikepung VOC, rupanya Sultan Ageng Tirtayasa menyelundupkan delapan kapal pencalang ke Lampung, untuk mencari bantuan dari sekutunya di Lampung (Bukry, 1997: 67).

Konsolidasi terus dilakukan Sultan Ageng untuk mempertahankan kuasanya atas Lampung. Sultan Ageng memerintahkan penguasa Menanga, Aria Sura Jaya, untuk menjatuhkan kedudukan Raja Ngombar di Semangka. Raja Ngombar memihak Sultan Haji dalam perang saudara di Banten. Semangka berhasil dikuasai, bahkan Raja Ngombar mengalami penawanan. Sementara itu, penduduk yang loyal terhadap Raja Ngombar harus membayar denda lima ringgit (Imadudin, 2008: 1484).

Pada tanggal 3 September 1682 berlangsung musyawarah antara Pangeran Nata Negara dan Aria Wangsa Yudha dengan pengganti Raja Ngombar. Turut dalam pertemuan itu para adipati Tengah,
Gunung Raja, Mulang Maya, Betung, Agung, Putih, Jalaang, Madan, dan Nahkoda Lebih. Kedua utusan Sultan Haji menjelaskan bahwa kekuasaan Banten atas Lampung beralih ke tangan VOC. Para adipati jangan terganggu dengan peralihan kekuasaan, dan terus bergiat meningkatkan produksi lada yang terus mengalami penurunan.

Pasukan Van der Schuur berhasil membebaskan Raja Ngombar dari penawanan pasukan Aria Sura Jaya di Pulau Legundi. Pengikut Aria Sura Jaya melarikan diri dari perairan Teluk Semangka. Rombongan ekspedisi kemudian memasuki Desa Ratai dengan tujuan mencari lada yang dibawa kapal-kapal dari Selebar (Bukry, 1997/1998: 68). Meriam ditembakkan sebagai tanda peringatan. Para penguasa Pedada, Punduh, Rata, Sabu, dan Menanga mengibarkan bendera putih. Perahu-perahu pembawa lada menyingkir ke arah hulu sungai. Nahkoda Kapala dan Panjang beserta pasukannya berupaya mempertahankan diri dengan membangun benteng pertahanan. Peperangan tidak berlanjut, karena Pangeran Dipa Ningrat dan Tuan Masyhur mampu meyakinkan penduduk. VOC membeli semua lada yang dibawa perahu-perahu dari Selebar. Harganya sebelas ringgit tiap baharnya (Bukry, 1997: 69).

Van der Schuur dan duta Banten gagal memperkuat dukungan Lampung terhadap Sultan Haji. Pertempuran pecah kembali di Teluk Lampung pada tanggal 11 Nopember 1682. Prajurit Raja Ngombar dikalahkan prajurit Lampung. Sebagian prajuritnya bergabung dengan penduduk. Raja Ngombar melarikan diri ke benteng VOC. VOC melakukan serangan balasan mengejar pasukan Lampung. Pengejaran tidak berlanjut, karena van der Schuur harus kembali ke Batavia. Persediaan logistik sudah menipis. Ekspedisi tersebut kembali ke Batavia melalui Banten pada tanggal 21 Nopember 1682, membawa 744.188 ton lada seharga $f 622.923$. Ekspedisi ini juga tidak membawa hasil yang memuaskan. 
Penguasaan Banten atas Lampung semakin mengendur pada permulaan abad ke-18. Konflik sesama perwakilan Banten di Lampung melemahkan kekuatan mereka. Hal tersebut terlihat ketika Kesultanan Palembang merebut Tulang Bawang, pasukan Banten tidak berdaya. Guna merebut kembali Tulang Bawang, Sultan Zainal Arifin meminta pertolongan VOC. Kekuasaan Banten dapat dipulihkan kembali setelah prajurit kompeni dikerahkan. VOC mendirikan Benteng Petrus Albertus di Menggala pada tahun 1738, khususnya mengawasi perdagangan lada di wilayah tersebut (Gonggong, 1993: 28).

Instabilitas politik terus berlangsung dalam Kesultanan Banten. Syarifah Fatimah (Ratu Fatimah) terlalu jauh mencampuri kebijakan yang diambil Sultan Abdulmahasin Muhammad Syafei Zainal Arifin (Gonggong, 1993: 28). Rupanya Ratu Fatimah adalah agen VOC yang diberi tugas melakukan perluasan kekuasaan di kalangan keluarga keraton Banten. Dalam situasi demikian, krisis kepercayaan melanda kesultanan dengan pecahnya pemberontakan Ki Tapa dari Gunung Menara. Pada waktu yang berdekatan, kekacauan terjadi di Lampung. Benteng Petrus Albertus di Menggala mampu dikuasai para pemberontak. Namun tidak berlangsung lama, karena prajurit tambahan dari Batavia berhasil merebut benteng tersebut (Imadudin, 2008: 1486).

Wilayah Lampung mengalami kekacauan karena tidak ada kekuasaan yang kuat. Masalah intern kesultanan Banten, keterbatasan tentara VOC, dan konflik sesama wakil Banten menjadi faktor penyebab kondisi demikian (Bukry, 1997: 69). Wilayah Lampung bagaikan terra incognito (wilayah tak bertuan) yang siapa pun bebas memasukinya.

Para perompak dari Johor, Bugis, dan Mandar memanfaatkan situasi tersebut. Mereka sering mengganggu para petani yang bertanam lada. Selain itu, para perompak juga menguasai jalur pengang- kutan lada. Keadaan menjadi tidak kondusif bagi perdagangan lada.

Perairan Selat Sunda juga menjadi sasaran perompakan sejak tahun 1760-an. Sejumlah kapal yang mengangkut lada mengalami penjarahan. Para perompak menukar hasil jarahannya dengan amunisi. Lada juga dibarter dengan opium dan tekstil.

Situasi tersebut dimanfaatkan para pedagang Inggris untuk mengambil keuntungan. Aktivitas kelompok pembajak tidak terlepas dari adanya kebutuhan para pedagang Cina dan Inggris yang menginginkan pembelian lada di luar kontrol VOC. Di Silebu, para pedagang Inggris membeli lada hasil jarahan. Tidak sampai di situ, para pedagang Inggris membantu aksi para perompak. Mereka mengatur para perompak untuk merampok lada dari kapal kargo yang melewati pulau Lagondi (Ota, 2005: 9).

VOC tidak tinggal diam melihat aksi pembajakan. VOC gagal mencegah aksi pembajakan, karena kapal-kapal Belanda kalah cepat dari kapal para perompak. VOC tidak berhasil menangkap para perompak yang bersembunyi di sekitar pulau-pulau kecil di Selat Sunda (Ota, 2005: 9).

Aksi perompakan di Lampung dan Selat Sunda tidak dapat dilepaskan dari tumbuhnya perdagangan inter-regional di Kanton. Permintaan produk dari Asia Tenggara mengubah perdagangan maritim di Nusantara. Para pedagang mengutamakan pelabuhan yang bebas dari dominasi VOC. ${ }^{4}$ Pusat-pusat lada, seperti Lampung, Palembang, Jambi, dan

\footnotetext{
${ }^{4}$ Riau, ibukota Kerajaan Johor, berkembang menjadi pusat perdagangan baru. Para pedagang Bugis mengangkut komoditi lada untuk dipertukarkan dengan komoditi dari Cina dan India di Riau. Menurut laporan, sekitar 10.000 pikul lada diperjualbelikan di Riau tahun 1780-an. Kemudian, para pedagang Cina dan Inggris membawanya ke Kanton untuk kemudian dijual ke pasaran Eropa.
} 
Banjarmasin masuk dalam sistem perdagangan Belanda. Oleh karena itu, "pembajakan" dan "penyelundupan" menjadi alternatif memperoleh lada (Ota, 2005: 9).

F.H. Beijnon, Komandan VOC di Banten, melaporkan kepada Gubernur Jenderal di Batavia tanggal 30 September 1792 tentang akibat dari perompakan. Sepanjang Januari 1791- September 1792 berlangsung aksi perampokan terhadap 18 desa dan 23 kapal di Lampung dan Selat Sunda. Para perampok memang melakukan aksinya hingga ke pedalaman Lampung (Marsden, 1999: 176). Para perampok menjarah 6.000 pikul lada. Bila dikalkulasikan, hasil pembajakan selama dua puluh satu bulan setara tiga puluh lima sampai tujuh puluh persen dari jumlah lada yang diperdagangkan di Riau. Jumlah tersebut sekitar dua puluh persen dari semua lada VOC yang diperoleh dari Lampung (Ota, 2005: 9).

Sasaran pembajak tidak hanya lada, tetapi juga tenaga kerja. Mereka yang ditangkap dijual ke pasar di Belitung, Lampung, dan daerah lainnya. Di Lampung, tenaga kerja tersebut dipekerjakan menjadi budak (Ota, 2005: 9).

Menyadari kegagalannya mencegah perompakan di Selat Sunda, VOC bergerak masuk ke pedalaman Lampung. Pada tahun 1738, atas seizin Sultan Banten, VOC mendirikan Benteng Valken Oog dekat Bumi Agung. Izin diberikan sebagai imbalan VOC menjadi hakim dalam sengketa tanah antara Banten dengan Palembang. Pada tahun 1751, Lampung dijadikan daerah pinjaman VOC dari Sultan Banten (Imadudin, 2008: 1487).

\section{Masa Hindia Belanda}

Besluit Gubernur Jenderal Daendels tertanggal 22 Nopember 1808 menyatakan bahwa pemerintah kolonial berkuasa penuh atas Lampung. Dasarnya adalah sejak Banten dikuasai, wilayahwilayah yang sebelumnya berada dalam pengaruh kekuasaan Banten, otomatis jatuh ke tangan Belanda (Sayuti, 1993).

Pemerintah kolonial menarik simpati penduduk Lampung dengan mengakui kepemimpinan lokal. Radin Inten I diakui pangkatnya sebagai ratu (prins regent) dan kurnel di negara ratu (Kalianda). Setelah pengalihan kekuasaan ke tangan Hindia Belanda tahun 1816, kekuasaan Radin Inten tidak diakui lagi (Rijal, 2011: 40).

Pada tahun 1817 dibuat kesepakatan antara Asisten Residen Krusemen dengan Radin Inten I yang isinya sebagai berikut:

1. Raden Inten I bersedia meninggalkan jalan kekerasan dan membantu pemerintah.

2. Radin Inten I akan diakui kedudukannya sebagaimana halnya pada masa Daendels.

3. Radin Inten I akan mendapat pensiun $f$ 1200 setahun dan saudara-saudaranya mendapat pensiun $f 600$ setahun.

Kesepakatan tersebut hanya mampu bertahan selama setahun. Lampung terus menerus mengalami kekacauan. Pada tahun 1818 pemerintah Hindia Belanda memerintahkan penguasa sipil militer (Civielen Militair Gezaghebber) menggantikan pemerintahan sipil (Veth, 1867: 107). Penguasa sipil milter berkewajiban mengamankan seluruh kepentingan Belanda di Lampung.

Radin Inten I memimpin penduduk Lampung menentang kolonial Belanda. Belanda menjulukinya "pemeras" dan "kepala batu". Salah satu bentuk penentangan Radin Inten adalah menjalankan perdagangan bebas dengan pihak lain (Ditjen Kebudayaan, 1969: 19). Radin Inten I menjual lada kepada Inggris dengan harga lebih tinggi dari ketetapan Sultan Banten (Ota, 2005: 9).

Pemerintah kolonial menuduh bahwa Radin Inten menjalin hubungan dengan para perompak, bahkan dikabarkan memiliki ikatan kekerabatan dengan bajak laut dari Lingga. Radin Inten I bahkan memberi para perompak perlindungan dan 
penampungan yang aman (Kielstra, 1919: 248).

Kondisi keamanan di wilayah Lampung tidak mampu dikontrol sepenuhnya oleh Belanda. Kekuatan Belanda terkuras menumpas perlawanan Pangeran Diponegoro (1825-1830). Oleh karena itu, wafatnya Radin Inten I menggembirakan pemerintah kolonial. Dengan demikian tidak ada lagi perlawanan dari rakyat Lampung.

Patah tumbuh, hilang berganti. Seorang pemimpin wafat, lahir pemimpin baru. Kepemimpinan Radin Inten I dilanjutkan Radin Imba II. Ketika tahun 1828 Belanda mendaratkan sebuah kapal perang dan dua kapal penjelajah ke Lampung, Radin Imba II menyambutnya dengan perlawanan sengit.

Belanda melancarkan politik pecah belah (devide et impera) di daerah-daerah yang dikuasainya dengan menghasut dan berbagai pelemahan lainnya. Menyadari bahwa kekuatannya sedang lemah, Belanda menawarkan perundingan gencatan senjata. Belanda mengulur waktu hingga mampu mengorganisasikan kembali pasukannya. Setelah kekuatan militer Belanda semakin kuat, serangan-serangan baru dilancarkan. Daerah utara Lampung yang jatuh ke tangan Belanda (Imadudin, 2008: 1490).

Kapten Hoffman memimpin penyerangan ke lokasi pendukung Radin Imba II pada tahun 1832. Dalam pertempuran di Semangka, Kapten Hoffman tewas terbunuh (Gonggong, 1993: 38). Kontak senjata berikutnya yang melibatkan Kapten Beelhoulder dan Kapten Pouwer berakhir dengan kekalahan di pihak Belanda.

Ekspedisi besar-besaran dipimpin Kolonel Elout dikerahkan pada tanggal 25 September 1834. Kekuatan Radin Imba II semakin berkurang. Benteng Raja Gepeh jatuh ke tangan Belanda pada 24 Oktober 1834. Radin Imba dan dua hulubalangnya yang setia, Raja Mangunang dan Lang Baruas melarikan diri ke Lingga (Kielstra, 1919: 257). Karena kuatnya tekanan
Belanda, Sultan Lingga terpaksa menyerahkannya ke tangan Belanda. Radin Imba dan Lang Baruas diasingkan ke Pulau Timor, sedangkan Raja Mangunang dibuang ke Batavia.

Setelah wafanya Radin Imba II tidak ada lagi elit lokal yang berwibawa. Bagi Belanda, hal tersebut sangat menguntungkan. Mereka tidak perlu menggelar pasukan mengahadapi perlawanan. Kekuatan Belanda sedang terkuras karena menghadapi Perang Padri di Minangkabau dan perlawanan Belgia yang hendak memisahkan diri (Ditjen Kebudayaan, 1969: 26).

Perjuangan Radin Imba dilanjutkan Radin Inten II. Radin Inten disumpah sebagai ratu oleh Haji Wakhia pada tahun 1850. Perwalian sementara dipegang Dalam Mangkubumi (18341850). Selama masa perwalian, tidak terjadi gejolak yang berarti (Bukry, 1997: 90).

Pusat pemerintahan Radin Inten II berada di Kuripan, wilayah selatan Lampung. Ia menguasai empat bandar, yaitu Bandar Penengahan, Bandar Legon, Bandar Pesisir/Ketibung, dan Bandar Rajabasa.

Sejak Radin Inten II berkuasa, perlawanan terhadap Belanda semakin meningkat. Karena situasi makin tidak aman, Belanda terus-menerus memindahkan pusat pemerintahannya mulai dari Ujau (Kalianda), Brunai (Teluk Semangka), Menggala, Bumi Agung, Terbanggi, dan Teluk Betung.

Upaya menghancurkan kekuatan Radin Inten II terus dilakukan Belanda. Kapten Yuch dengan berkekuatan 400 tentara pada tahun 1851 memimpin serangan Belanda ke Benteng Merambung. Dibantu Haji Wakhia dan para hulubalang, Radin Inten berhasil mematahkan serangan tersebut (Sayuti, 1993; Kartodirdjo, 1984: 180). 


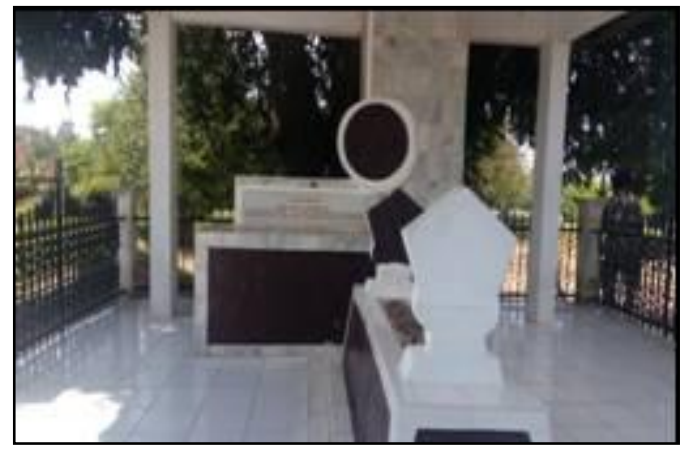

Gambar 1. Makam Radin Inten II di Kalianda Lampung Selatan Sumber: Iim Imadudin, 2016

Penduduk Lampung tidak berdiam diri diserang Belanda. Dipimpin Radin Inten II, serangan rakyat Lampung benarbenar merepotkan Belanda. Karena posisi mulai terdesak, pada tahun 1853 Asisten Residen J.E. Kohler menawarkan gencatan senjata. Gencatan tersebut hanya berlaku sebentar. Pada tahun 1855-1856 pertempuran sengit kembali berkobar. Perlawanan rakyat Lampung makin mendesak posisi Belanda. J.E. Kohler meminta didatangkan pasukan tambahan untuk memperkuat kedudukannya.

Bantuan pasukan segera didatangkan. Kolonel Waleson memimpin ekspedisi militer ke Lampung pada tanggal 10 Agustus 1856. Ekspedisi tersebut membawa 9 kapal perang, 3 kapal pengangkut logistik, dan puluhan perahu mayang dan jung mendarat di Pulau Sikepal, Teluk Tanjung Tua (Bukry, 1997: 94). Waleson memerintahkan agar Radin Inten II segera menyerah. Untuk memecah belah kekuatan Radin Inten II, Belanda mengajak Singa Branta yang bertahan di Benteng Bendulu untuk berunding (Imadudin, 2008: 1494).

Melalui pertempuran sengit, Benteng Bendulu mampu direbut Belanda. Benteng tersebut dijadikan basis operasi penghancuran benteng-benteng pertahanan Radin Inten II. Benteng Merambung, Benteng Galah Tanah, Pematang Sentok, dan Ketimbang berhasil dikuasai. Dipimpin Letnan Steck Benteng Rogoh berhasil dikuasai pasukan Belanda. Haji
Wakhia tertangkap, sedangkan putranya tewas dalam pertempuran.

Pada tanggal 9 September 1856, Wa' Maas mengalami luka berat sampai wafatnya. Haji Wakhia yang ditawan dan dihukum mati. Jenazahnya dimakamkan di Kunyain (Bukry, 1997/1998: 98; Kartodirdjo, 1984: 181).

Posisi Radin Inten II kian terpojok dengan tertangkapnya para pembantu utama dan kerabatnya. Benteng Ketimbang yang strategis direbut Belanda. Radin Inten II wafat disebabkan pengkhianatan Radin Ngerapat. Radin Ngerapat mengundang Radin Inten II untuk berunding di suatu daerah dekat Kunyian antara Tatahan dan Gayam (Sayuti, 1993; Bukry, 1997/1998: 98).

Pada saat Radin Inten II menikmati hidangan yang disediakan, Radin Ngerapat dan pengikutnya melakukan penyergapan. Radin Inten II melakukan perlawanan, meski tanpa dukungan pasukan. Dalam penyergapan tersebut, Radin Inten II gugur pada pukul setengah dua belas malam tanggal 5 Oktober 1856 (Gonggong, 1993: 66).

Belanda berkuasa penuh atas Lampung Sejak 1856. Dapat dikatakan penguasaan pemerintah kolonial atas Lampung semakin mantap. Lada tidak menjadi komoditas unggulan pada abad ke-19. Meski demikian, harga jual lada masih stabil. Meski mengalami penurunan, lada hitam Lampung masih yang terbaik di kawasan Sumatera.

Antara tahun 1816-1830 pemerintah kolonial memberlakukan sistem sewa tanah (landdelijk stelsel). Sistem sewa tanah bertujuan menghilangkan kefeodalan dan menjunjung aspek kebebasan. Sistem ini mengalami kegagalan. Dalam konteks Lampung, kuatnya ikatan jenang dengan petani lada menjadi penghalangnya. Tentu saja, jenang ingin tetap berperan dalam mata rantai perdagangan lada. 
Pemerintah kolonial menerapkan sistem tanam paksa pada tahun 18301870. Lada tidak lagi menjadi tanaman utama satu-satunya. Komoditas kopi, tebu, dan indigo mulai diperkenalkan pada tahun 1830. Lada menjadi tanaman yang wajib ditanam dalam skala kecil dalam sistem tanam paksa.
(Koloniaal Verslag 1912) tidak tercatat adanya perkebunan lada di Lampung.

Pusat penanaman di Lampung tetap terkonsentrasi di Tulang Bawang, Sepoetih, dan Sekampung. Pada masa ini dilakukan sistem verlag, yaitu pemilik modal meminjam dari pedagang untuk membuka lahan lada. Jenang tidak segan-

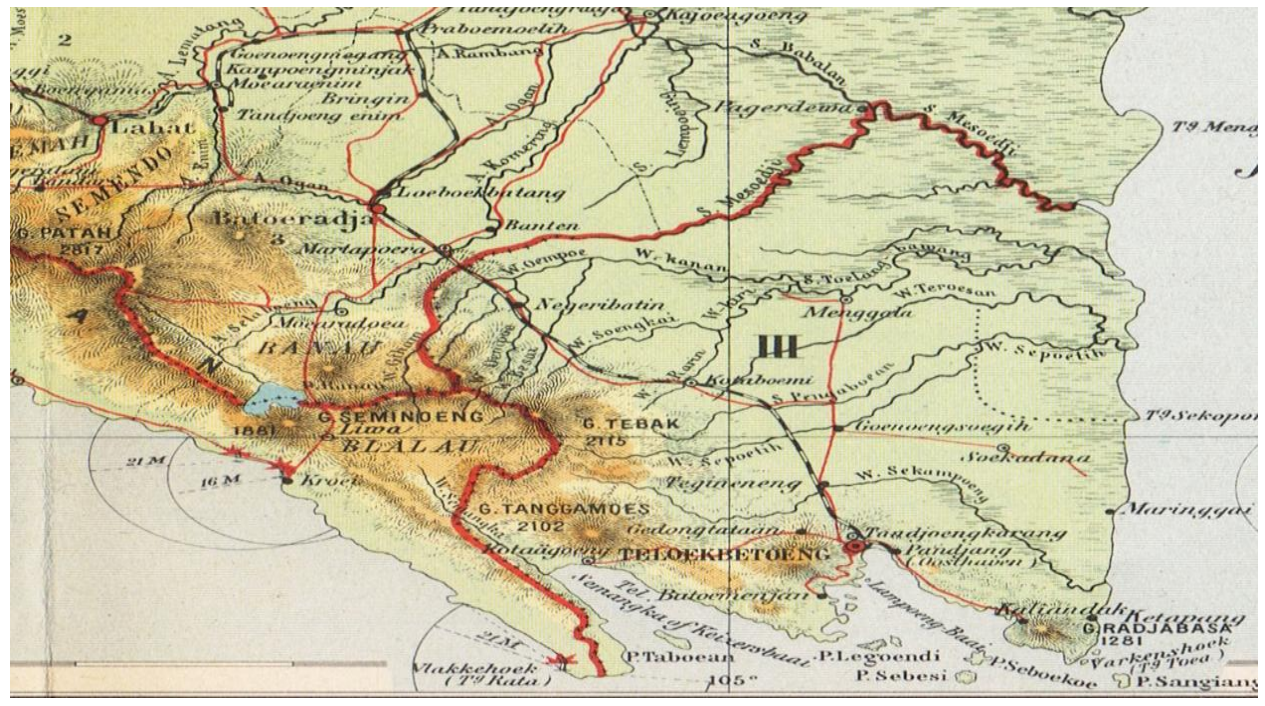

Peta 1. Distrik Lampung 1930

Sumber: Broersma, 1916

Para petani harus menyerahkan lada sebagai pajak kepada pemerintah kolonial. Menyadari kegagalan sistem sewa tanah, pemerintah tetap memfungsikan peran jenang untuk memerintahkan petani menanam lada. Para pengolah kebun dikontrak untuk menanam lada dalam jumlah tertentu; 1000 batang bagi pengolah berkeluarga dan 500 batang bagi pria lajang (Marsden, 2013:163). Pemerintah kolonial memberikan gaji kepada jenang sebagai imbalan mengumpulkan hasil produksi.

Pada tahun 1870 diberlakukan Undang-Undang Agraria sebagai pengganti sistem tanam paksa. Melalui undangundang, tanah Hindia Belanda terbuka bagi pemodal asing. Maka muncullah perkebunan-perkebunan dengan komoditas berorientasi ekspor yang bersaing dengan tanaman lada. Dalam Bijlage OO segan memberi pinjaman pada petani. Bahkan jenang memberikan uang muka lebih dahulu untuk lada yang akan dibeli (Masroh, 2015: 70). Selain itu, dilakukan pula sistem bagi hasil (menyasih).

Selain peran jenang dan pemilik tanah, juga tidak dapat dikesampingkan keberadaan para kuli kebun. Kuli merupakan pekerja lapangan. Scheltema membagi kuli atau budak di Lampung ke dalam bai dan bedua. Bai adalah budak pustaka. Bai diwajibkan untuk mengolah dan merawat sawah, kebun lada, dan sebagainya, milik tuannya, tetapi bai dapat pula mengumpulkan untuk dirinya sendiri. Sementara itu, bedua adalah seorang budak atau kuli yang tidak diperkenankan memiliki apa-apa, semua pekerjaan dan hasilnya untuk tuannya.

Setelah berakhirnya pergolakan di Lampung produksi perkebunan semakin meningkat. Kekacauan yang terjadi 
menyebabkan distribusi barang terganggu. Kelangkaan komoditas mengakibatkan harga barang menjadi naik.

Dalam Economisch Statistische Berichten 5 April 1922 No. 327 disebutkan kota-kota besar di Asia dan Australia, Eropa, dan Amerika, menjadi pasar lada. Kota yang menjadi pasar di Asia dan Australia adalah Kobe, Melbourne, dan Sidney. Kota-kota di Eropa, antara lain Amsterdam, London, Hamburg, Havre, Bordeaux, Marseille, dan Trieste; sedangkan pasar lada di Amerika, yakni New York dan San Fransisco (Masroh, 2015: 73).

Pelabuhan Batavia menjadi entreport yang mengumpulkan lada dan menjualnya ke pasar lada internasional melalui Nederland dan Singapura. HindiaBelanda menjadi produsen lada utama dengan tiga perempat produksi lada di Dunia.

Selama Perang Dunia Pertama, permintaan akan lada makin meningkat. Tercatat jumlah ekspor lada hitam Hinda Belanda sebanyak 246.794 pikul. Mulamula harga lada mencapai $f 50$, mengalami penurunan menjadi $f 29$, naik kembali menjadi $f 40$ dan stabil di posisi harga $f 47$ (Masroh, 2015: 75).

Pada tahun 1940 terdapat 39 kebun lada. Dapat dikatakan selama perang, harga lada di pasaran Eropa melonjak. Ketika perang berakhir, ekspor lada ke Eropa amat berkurang. Kondisi tersebut berbanding sebaliknya dengan kawasan lain. Di kawasan Asia, Afrika, Australia, dan Amerika, permintaan akan lada tetap tinggi.

Pada tahun 1930, Lampung mengekspor $12.920 .475 \mathrm{~kg}$ lada hitam ke luar negeri, yang berarti $76 \%$ dari seluruh total ekspor lada hitam di Hindia Belanda. Sementara itu, lada hitam yang dikirim ke wilayah Hindia Belanda mencapai $2.894 .973 \mathrm{~kg}$. Total lada hitam yang diekspor mencapai $15.815 .448 \mathrm{~kg}$. Sampai permulaan abad ke-20, Lampung merupakan salah satu penyuplai lada terbesar bagi Belanda yang memegang kontrol atas tiga perempat produksi lada dunia (Guillot, 1990: 32).

Penanaman dan perdagangan lada di Lampung terus memudar pada abad ke20. Pada tahun 1930 menyebar penyakit kuning yang merusak kebun-kebun lada. Merebaknya walang sangit pemakan bunga dan buah lada menjadi persoalan tersendiri (Masroh, 2015: 74).

Pemeliharaan kebun lada yang kurang baik mengakibatkan menurunnya kualitas tanaman lada. Tanaman lada memiliki siklus produksi. Begitu muncul tanda-tanda penurunan kualitas, harus segera dilakukan pembaruan atau pembuatan kebun baru yang dapat mulai memberi hasil sebelum produksi kebun lama terhenti (Marsden, 2013:159). Lada Lampung hanya bertahan selama 15 tahun atau lebih cepat mati dibandingkan jenis lada Muntok yang mencapai 30 tahun. Lada Lampung dipanen pada usia 2 sampai 2,5 tahun. Setiap tahun lada hanya dipanen satu kali. Kurangnya pemupukan dan kekeringan yang terus terjadi menurunkan unsur hara tanah. Produksi lada terus mengalami penurunan. Namun, sepuluh tahun kemudian, jumlahnya terus merosot, tinggal 12 kebun. Berkurangnya jumlah kebun tentu berdampak pada produksi. Bila pada tahun 1940 dihasilkan 100 ton lada, pada tahun 1950 berkurang menjadi produksi 23 ton.

\section{PENUTUP}

Penanaman dan perdagangan lada dalam tiga sistem politik bergerak dinamis. Perebutan pengaruh dalam perdagangan lada di kawasan Lampung tercipta dalam pola dominasi dan subordinasi.

Pada masa kejayaan Kesultanan Banten, Lampung merupakan sumber lada yang penting bagi ekonomi Banten. Memang ada Kesultanan Palembang yang mencoba bersaing dengan Banten, namun pengaruhnya terbatas. Sultan Banten menetapkan peraturan yang terkait dengan penanaman dan tata niaga lada. Kesultanan Banten melakukan kontrol yang ketat 
terhadap penanaman lada di Lampung melalui jenang dan punggawa. Lampung dalam jangka waktu yang cukup lama memberi surplus pada Kesultanan Banten.

Pada masa VOC, para pedagang asing berlomba mendapatkan konsesi lada. Berlangsung persaingan hebat di antara para pedagang itu. Dalam perdagangan lada,VOC melakukan praktik monopoli dan monopsoni. VOC bertindak sebagai penjual dan pembeli yang melakukan monopoli.

Pada masa Hindia Belanda, pemerintah melakukan eksploitasi ekonomi melalui berbagai sistem. Ketika pemerintah memberlakukan sistem sewa tanah, pengembangan produksi lada tidak berjalan dengan baik. Demikian juga, ketika sistem tanam paksa diberlakukan, lada tidak menjadi komoditas utama yang wajib ditanam. Barulah ketika Agrarische Wet diterapkan 1870, tumbuh perkebunanperkebunan lada yang baru. Kekuasaan yang penuh pada pihak swasta mengakibatkan produksi meningkat.

Runtuhnya kejayaan lada Lampung terjadi pada awal abad ke-20. Selain karena faktor internal, seperti pemeliharaan kebun lada yang tidak optimal, menurunnya keseburan tanah, dan penyakit tanaman, juga faktor eksternal. Lada tidak lagi menjadi komoditas yang penting di pasaran dunia. Memudarnya perdagangan lada selain disebabkan menurunnya permintaan dari pasar internasional, juga diakibatkan oleh monopoli pedagangan lada oleh kekuatan asing.

Belajar dari penguasaan tiga sistem politik tersebut, menjadi jelaslah bahwa para petani lada menjadi objek eksploitasi kalangan bangsa sendiri dan pihak kolonial. Penduduk Lampung yang menjadi petani dan kuli tidak mengalami kesejahteraan yang signifikan. Bila ada yang diuntungkan dalam tata niaga lada adalah elit-elit lokal yang bekerja untuk kepentingan suprastruktur. Meski demikian, Radin Inten I, Radin Imba II, dan Radin Inten II adalah sedikit dari kelompok elit yang memperjuangkan hakhak rakyatnya.

Tiga abad silam perdagangan lada di Lampung mencapai masa kejayaannya. Bila hari ini, pemerintah dan masyarakat Lampung berusaha membangkitkan kembali penanaman lada memiliki dasar historisnya. Para petani di kantong-kantong penghasil lada yang ada sejak dulu sampai sekarang masih bertanam lada dalam skala kecil, antara lain di Lampung Utara, Lampung Selatan, dan Kotabumi. Namun, di luar itu lebih banyak lagi yang sudah meninggalkan lada berganti dengan tanaman komersial lainnya, karena zaman sudah berganti.

\section{DAFTAR SUMBER \\ 1. Jurnal dan Makalah}

Hardjasaputra, Sobana. "Penanaman Nilai-nilai Kesejarahan di Jawa Barat", makalah seminar yang diselenggarakan Disparbud Provinsi Jawa Barat, 26-27 Maret 2013 di Hotel Savoy Homann Bandung.

Imadudin, Iim.

"Hubungan Lampung-Banten dalam Perspektif Sejarah", dalam Jurnal Penelitian Vol. 40 No. 3 Desember 2008, hlm. 1433-1502.

2016.

"Perdagangan Lada dan Perebutan Pengaruh di Lampung 1653-1856", Makalah dalam Seminar Hasil Penelitian BPNB se-Indonesia, Makasar, 25 s.d. 28 April 2016.

Masroh, Laelatul.

"Perkebunan dan Perdagangan Lada di Lampung Tahun 1816-1942”, SEJARAH DAN BUDAYA, Tahun Kesembilan, Nomor 1, Juni 2015.

Nur, Mhd. "Bandar Tiku di Bagian Barat Sumatra: Kejayaan Ekonomi yang Telah Hilang", Analisis Sejarah, Volume 4, No. 2, 2014, hlm. 16-34. 


\section{Buku}

ANRI. 1973.

Ikhtisar Keadaan Politik Hindia

Belanda Tahun 1839-1848. Jakarta:

Penerbitan Sumber-sumber Sejarah

ANRI.

Bukry et al. 1997/1998.

Sejarah Daerah Lampung. Lampung:

Depdikbud.

Cortesão, Armando. 2015.

Suma Oriental Karya Tome Pires: Perjalanan dari Laut Merah ke Cina \& Buku Francisco Rodrigues. Terjemahan Adrian Perkasa dan Anggita Pramesti. Yogyakarta: Ombak.

Ditjen Kebudayaan. 1969.

Perdjuangan Pahlawan Radin Inten. Lampung: tp.

Drewes, G.W.J. 1961.

De Biografie van een Minangkabausen Peperhandelaar in de Lampongs. S'Gravenhage: Martinus Nijhoff.

Ekadjati, Edi S. 1997.

"Kesultanan Banten dan Hubungannya dengan Wilayah Luar", dalam Sri Sutjiatiningsih (ed.). Banten Kota Pelabuhan Jalur Sutra: Kumpulan Makalah Diskusi. Jakarta: Direktorat Jenderal Kebudayaan Depdikbud.

Gonggong, Anhar (eds.). 1993.

Sejarah Perlawanan terhadap Imperialisme dan Kolonialisme di Daerah Lampung. Jakarta: Depdikbud.

Gottschalk, Louis. 1985.

Mengerti Sejarah. Terjemahan Nugroho Notosusanto). Jakarta: UI Press.

Guillot, Claude. 1990.

The Sultanate of Banten. Jakarta: Gramedia Book Publishing Division.

Johnson, Doyle Paul. 1986.

Teori Sosiologi Klasik dan Modern 1. Terjemahan Robert M.Z. Lawang. Jakarta: Gramedia.

Juliadi (ed.) 2014.

Khasanah Budaya Lampung. Serang: Balai Pelestarian Cagar Budaya Serang.

Kartodirdjo, Sartono. 1984.

Pemberontakan Petani Banten 1888. Jakarta: Pustaka Jaya.
1987.

Pengantar Sejarah Indonesia Baru: 1500 dari Emporium ke Imperium (Jilid I). Jakarta: Gramedia.

Kielstra, EB. "De Lampongs", Onze Eeuw, jaargang 15. 1919.

Kuntowijoyo. 2003.

Metodologi Sejarah. Edisi Kedua. Yogyakarta: Yogyakarta.

Ota, Atsushi, 2015.

"Toward a Transborder, Market Oriented Society: Changing Hinterlands of Banten, c. 1760-1800”, dalam Mizushima, Tsukasa, George Bryan Souza, Dennis O. Flynn (eds.), Hinterlands and Commodities: Place, Space, Time and Political Economic development of Asia Over the Long Eighteenth Century. Koninklijke Brill NV. Leiden, p. 166-196.

Ota, Atsushi, "From 'Piracy' to Inter-regional trade”, IIAS Newsletter, March 2005.

Rijal, Andi Syamsu. 2011.

Dua Pelabuhan Satu Selat: Sejarah Pelabuhan Merak dan Pelabuhan Bakauheni di Selat Sunda 1912-2009. Tesis. Depok: Fakultas Ilmu Pengetahuan Budaya Program Studi Sejarah Universitas Indonesia.

Saptono, Nanang.

"Model Pertukaran Lampung Banten pada Abad ke-16-18 M", dalam Naniek Th. Harkantiningsih (ed.), Perdagangan dan Pertukaran Masa PrasejarahKolonial. Bandung: Balai Arkeologi Bandung, hlm. 82-94.

Sayuti, Husin.

"Sistem Pemerintahan Lampung", dalam Sejarah Perkembangan Pemerintahan di Daerah Lampung. Bahan Seminar, Februari 1993.

1993.

Seputeh Lampung. Kualalumpur: Dewan Bahasa dan Pustaka.

Untoro, Heriyanti Ongkodharma. 1998. Perdagangan di Kesultanan Banten (1522-1684): Kajian Arkeologi Ekonomi. Disertasi. Depok: PPs UI. 
2006.

Kebesaran dan Tragedi Kota Banten.

Jakarta: Kota Kita.

Veth, P.J. 1867.

Schets van het Eiland Sumatra.

Amsterdam: P.N. van Kampen.

Yusuf, Tayar et al. 1984/1985.

Sejarah Sosial Daerah Lampung.

Jakarta: Depdikbud.

Weber, Max. 1978.

Economy and Society. London:

University of California Press. 